\title{
High Grade Prostatic Intraepithelial Neoplasia, Signet Ring Variant
}

National Cancer Institute

\section{Source}

National Cancer Institute. High Grade Prostatic Intraepithelial Neoplasia, Signet Ring

Variant. NCI Thesaurus. Code C39887.

High grade prostatic intraepithelial neoplasia characterized by the presence of signet ring cells in the affected glands. 